OPEN ACCESS

Citation: Sazada Siddqiui, Saad Abdurahamn Muhammad Al Amri, Huda Ahmed Al Ghamdy, Wadha Saad Saeed Alqahtani, Sarah Mohammed Alquyr, Habab Merghani Yassin (2021) Impact of Bisphenol A on seed germination, radicle length and cytogenetic alterations in Pisum sativum L.. Caryologia 74(2): 103-109. doi: 10.36253/caryologia-1230

Received: March 02, 2021

Accepted: June 11, 2021

Published: October 08, 2021

Copyright:@2021 Sazada Siddqiui, Saad Abdurahamn Muhammad Al Amri, Huda Ahmed Al Ghamdy, Wadha Saad Saeed Alqahtani, Sarah Mohammed Alquyr, Habab Merghani Yassin. This is an open access, peer-reviewed article published by Firenze University Press (http://www.fupress.com/caryologia) and distributed under the terms of the Creative Commons Attribution License, which permits unrestricted use, distribution, and reproduction in any medium, provided the original author and source are credited.

Data Availability Statement: All relevant data are within the paper and its Supporting Information files.

Competing Interests: The Author(s) declare(s) no conflict of interest.

ORCID

SS: 0000-0001-5448-7617

\section{Impact of Bisphenol A on seed germination, radicle length and cytogenetic alterations in Pisum sativum $\mathrm{L}$.}

\author{
Sazada Siddiqiui*, SaAd Abdurahamn Muhammad Al Amri, Huda \\ Ahmed Al Ghamdy, Wadha Saad Saeed Alqahtani, Sarah Mohammed \\ Alquyr, Habab Merghani Yassin \\ Department of Biology, College of Science, King Khalid University, Abha 61413, Saudi \\ Arabia \\ ${ }^{*}$ Corresponding author. E-mail: sasdeky@kku.edu.sa
}

\begin{abstract}
Bisphenol A (BPA) is a global transpiring pollutant and an endocrine disruptor present in the environment which has a substantial harmful effect on plants. In the present study, its effects on seed germination, radicle length and cytogenetic alterations were investigated in $P$. sativum root tip cells. $P$. sativum seeds were germinated after treating with various concentrations of BPA $(2 \mathrm{mg} / \mathrm{L}, 5 \mathrm{mg} / \mathrm{L}, 10 \mathrm{mg} / \mathrm{L}, 15$ $\mathrm{mg} / \mathrm{L}, 20 \mathrm{mg} / \mathrm{L}$ and $25 \mathrm{mg} / \mathrm{L}$ ) at $24 \pm 1^{\circ} \mathrm{C}$ for 72 hours and the cytogenetic variations were assessed. The investigation showed that BPA reduced the percentage of seed germination, mitotic index, radicle length (at higher concentrations) and instigated a rise in chromosomal anomalies in a dose-related manner. In total, there is an enhanced occurrence of c-mitosis, stickiness, bridges, fragments and laggards in the BPA treated root tip cells of $P$. sativum seeds.
\end{abstract}

Keywords: BPA, Seed germination, Mitotic index, Chromosomal anomalies, Pisum sativum $\mathrm{L}$.

\section{INTRODUCTION}

Bisphenol A (BPA, 2,2-bis-(4- hydroxyphenyl) propane) is an important transpiring pollutant (Clarke and Smith 2011). BPA is an abundantly mass-produced industrial chemical widely used in the manufacture of various domestic and daily use items like baby feeding plastic bottles, protecting coverings, packing of drinks, food items and in the linings of metal cans used for storing beverages and food products. Globally every year BPA is manufactured industrially in huge quantities approximately 0.0037 billion metric tonnes (Mihaich et al. 2009). It is constantly released in marine environment by municipal, agriculture and industrial effluents (Gatidou et al. 2007; Pothitou and Voutsa 2008; Fu and Kawamura 2010). With leaching of BPA by plastics and containers used for keeping food, drinks and beverages, human beings are exposed to it by consuming food and drinks stored in 
these containers (Huang et al. 2012) and it poses a risk for the health of all human beings (Le et al. 2008; Wagner and Oehlmann 2009; Cooper et al. 2011). Human beings are also at risk by eating fish found in aquatic waters polluted by BPA (Mita et al. 2011). Agrarian soils usually get polluted by biosolids containing BPA found in sewage sludge (Gatidou et al. 2007; Stasinakis et al. 2008). Through extensive research work on BPA, it has been found that it is an endocrine disruptor (Staples et al. 1998; Le et al. 2008; Clarke and Smith 2011). Small organisms living in soils and plants could come in contact with soils polluted by BPA (Yamamoto et al. 2001; Staples et al. 2010). Moreover, not many studies have analyzed the toxicologic effects of BPA in plants which absorbs and accumulates it (Ferrara et al. 2006). Though, it has been established that plants can form BPA-glycosides by metabolizing BPA (Noureddin et al. 2004), clastogenic as well as phytotoxic influence of BPA were defined (Ferrara et al. 2006). Due to the impact of BPA on the pollen of kiwifruit in a dose-related manner, there is a substantial inhibition of tube development and its elongation (Speranza et al. 2011). Lately, the mitotic and chromosomal anomalies were found in cells of root meristem of Allium cepa L treated with 50, 100, 150 and $200 \mathrm{mg} / \mathrm{L}$ BPA concentration for five days (Jadhav et al. 2012). BPA treatment with 0.044-0.44 mM concentration inhibited the segregation of chromosomes, obstructed the cytokinesis completion, disrupted mitotic MT arrays and interphase and stimulated microtubules creation in P. sativum (Adamakis et al. 2013). Moreover, BPA treatment influences leaf blade differentiation in Arabidopsis thaliana significantly (Pan et al. 2013) and in BPA treated seedlings of soybean, it reduced the photosynthetic constraints and growth indexes (Qiu et al. 2013).

In animals, Bisphenol $\mathrm{A}$ has revealed to put forth xenoestrogenic action (Wang et al. 2021). However, the influence of BPA on plants are not clearly understood. Though BPA is consumed regularly and disposed, it may persist in the soil and can potentially cause detrimental effects on the plants. Further, there is not sufficient studies available in the literature about its genotoxic effects on plants (Palani and Panneerselvam 2007). In the present study, we have evaluated the adverse effects of BPA on seed germination, radicle length, mitotic index and chromosomal anomalies in cells of $P$. sativum root tips.

\section{MATERIAL AND METHODS}

\section{Purchase of BPA and seeds}

From a seed shop in Saudi Arabia, pea seeds ( $P$. sativum variety ARKIL, $2 n=14$ ) were bought. Through
Sigma-Aldrich Merck (Darmstadt, Germany) Bisphenol A (BPA) (BPA, 2,2-bis-(4- hydroxyphenyl) propane is procured from Bayouni Trading Co. Ltd., Jeddah, Saudi Arabia. Bisphenol A, CAS number is 80-05-7. Its melting point is $158-159^{\circ} \mathrm{C}$ and its solubility in water at $25^{\circ} \mathrm{C}$ is $123-300 \mathrm{mg} / \mathrm{L}$. The molecular weight of BPA is 228.29 and its chemical formula is $\mathrm{C}_{16} \mathrm{H}_{18} \mathrm{O}_{2}$.

\section{Seed treatment with BPA}

For 5 minutes, seeds were sterilized in $0.1 \% \mathrm{HgCl}_{2}$ solution and they were washed in distilled water 2-3 times. Thirty seeds were soaked in BPA solutions of each concentrations $(2 \mathrm{mg} / \mathrm{L}, 5 \mathrm{mg} / \mathrm{L}, 10 \mathrm{mg} / \mathrm{L}, 15 \mathrm{mg} / \mathrm{L}, 20$ $\mathrm{mg} / \mathrm{L}$ and $25 \mathrm{mg} / \mathrm{L}$ ) for 3 hours. For control group, a group of thirty seeds was soaked in distilled water. Seeds were repeatedly shaken for sufficient air supply. Thirty sterilized seeds were then spread over three Whatman filter papers, grade one and then kept in Petri-dishes (150 $\mathrm{mm} \times 15 \mathrm{~mm}$ diameter). For more readings, these Petri dishes were kept in a Biological Oxygen Demand incubator (BOD) at a temperature of $24 \pm 2^{\circ} \mathrm{C}$. As per the procedure defined by Rank (2003), root elongation toxicity and seed germination tests were performed. Radicle length were measured and germination of seeds were recorded, each day on an interval of 24 hours for 3 consecutive days. In similar settings, this test was done thrice. Toxicity was stated as compared with control, the difference of germination of seeds and root elongation.

\section{Cytotoxicity and genotoxicity evaluations}

To assess the cytotoxicity and genotoxicity evaluations caused by BPA in P. sativum plant, the root tips of germinated seeds were used as a source of mitotic cells. The root tips were washed in water. In a blend of ethanol and acetic acid (3:1-v/v, Merck), roots in length $2 \mathrm{~cm}$ were fixed (approximately 2 days). Staining of fixed roots were done with Schiff's reagent, as defined by Feulgen and Rossenbeck (Mello and Vidal 1978) and the slides were made by applying the meristematic region as per the protocol stated by Siddiqui et al. (2007). By documenting the variations in the meristematic cells mitotic index (MI), cytotoxicity was evaluated. By means of scoring various kinds of chromosomal anomalies (CAs), genotoxicity was assessed.

Each slide was observed and coded blind. By using light microscope under oil immersion, chromosomal anomalies and mitotic index in metaphase and anaphase plates were examined. At least 250 cells were scored from every single slide and mitotic index was computed. Chromosomal anomalies such as sticky chromosome, 
c-mitosis, laggards, bridges and fragments were examined in at least 150 metaphase and anaphase plates for each slide and stated in percentage.

\section{Statistical analysis}

By using Graph Pad software (San Diego, CA, USA), statistical analysis (ANOVA with Dunnett's multiplecomparison test) having significance at $\mathrm{P}<0.05$ was carried out. Data were exhibited in the form of mean \pm standard error (SE).

\section{RESULTS}

\section{Effect of BPA treatment on seed germination}

At $24 \mathrm{~h}$ interval, in control group $77.33 \%$ of seeds germinated which increased to $85 \%$ and $99 \%$ at $48 \mathrm{~h}$ and 72 $\mathrm{h}$ respectively (Table 1$)$. In seeds treated with lower concentration of BPA ( 2 and $5 \mathrm{mg} / \mathrm{L})$, percentage of seed germination decreased $(\mathrm{p}<0.001$ and $\mathrm{p}<0.05)$ at $24 \mathrm{~h}$. Similarly, a significant decrease was observed at $48 \mathrm{~h}(\mathrm{p}>0.05)$ and $72 \mathrm{~h}(\mathrm{p}<0.01$ and $\mathrm{p}<0.001)$ compared to control. In all time periods, on and above a concentration of $10 \mathrm{mg} / \mathrm{L}$ treatment with BPA caused a very significant decrease in germination percentage of seed in a dose-related manner, as compared to control. Lowest percentage of seed germination was reported at $20 \mathrm{mg} / \mathrm{L}(65 \%$ at $72 \mathrm{~h})$ and at 25 $\mathrm{mg} / \mathrm{L}(50.22 \%$ at $24 \mathrm{~h}, 60 \%$ at $48 \mathrm{~h})$ in BPA treated seeds.

\section{Effect of BPA treatment on radicle length}

In control group, the radicle length increased with increase in time which was $4.0 \pm 0.05$ at $72 \mathrm{~h}$ (Fig. 1).

Table 1. Germination rates of P. sativum treated with different concentrations of BPA.

\begin{tabular}{lccc}
\hline \multirow{2}{*}{$\begin{array}{l}\text { Concentrations } \\
\text { of BPA }\end{array}$} & \multicolumn{3}{c}{ Seed germination (\%) } \\
\cline { 2 - 4 } & $24 \mathrm{~h}$ & $48 \mathrm{~h}$ & $72 \mathrm{~h}$ \\
\hline 00.00 & $77.33 \pm 0.33$ & $85.0 \pm 0.88$ & $99.0 \pm 3.11$ \\
$2 \mathrm{mg} / \mathrm{L}$ & $72.77 \pm 0.88^{\mathrm{a}}$ & $84.0 \pm 0.68$ & $88.0 \pm 2.09^{\mathrm{b}}$ \\
$5 \mathrm{mg} / \mathrm{L}$ & $74.33 \pm 0.77^{\mathrm{c}}$ & $78.0 \pm 3.20$ & $82.2 \pm 0.33^{\mathrm{a}}$ \\
$10 \mathrm{mg} / \mathrm{L}$ & $66.66 \pm 0.15^{\mathrm{a}}$ & $70.0 \pm 1.15^{\mathrm{a}}$ & $75.0 \pm 0.88^{\mathrm{a}}$ \\
$15 \mathrm{mg} / \mathrm{L}$ & $61.22 \pm 0.03^{\mathrm{a}}$ & $68.0 \pm 1.15^{\mathrm{a}}$ & $70.0 \pm 1.33^{\mathrm{a}}$ \\
$20 \mathrm{mg} / \mathrm{L}$ & $55.33 \pm 0.66^{\mathrm{a}}$ & $61.0 \pm 0.88^{\mathrm{a}}$ & $65.0 \pm 0.77^{\mathrm{a}}$ \\
$25 \mathrm{mg} / \mathrm{L}$ & $50.22 \pm 0.42^{\mathrm{a}}$ & $60.0 \pm 0.55^{\mathrm{a}}$ & $65.6 \pm 0.66^{\mathrm{a}}$ \\
\hline
\end{tabular}

${ }^{\mathrm{a}} \mathrm{p}<0.001$ compared to control; ${ }^{\mathrm{b}} \mathrm{p}<0.01$ compared to control; ${ }^{\mathrm{c}} \mathrm{p}<0.05$ compared to control.

Data are mean of three replicates \pm SEM; $00.00=$ Control group .

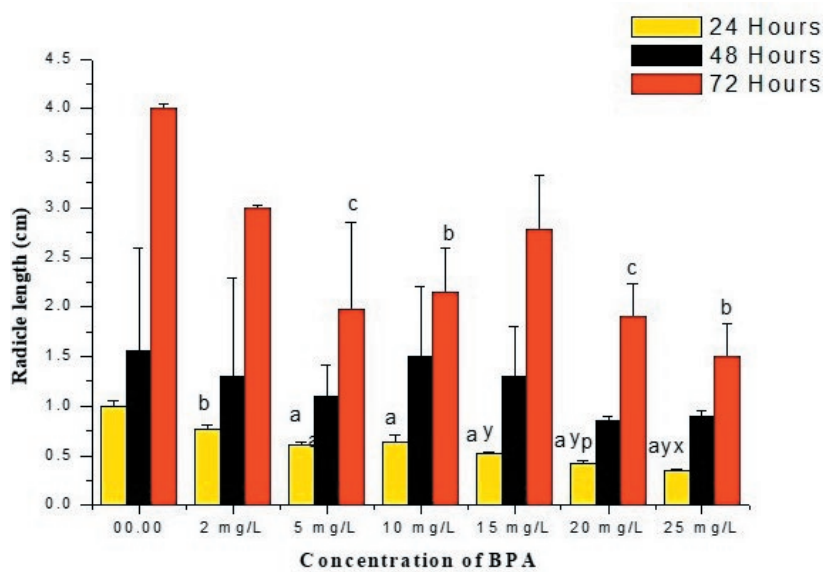

Figure 1. Effect of different concentrations of BPA on the radicle length of $P$. sativum. ${ }^{\mathrm{a}} \mathrm{p}<0.001$ compared to control; ${ }^{\mathrm{b}} \mathrm{p}<0.01 \mathrm{com}-$ pared to control; ${ }^{c} \mathrm{p}<0.05$ compared to control. ${ }^{\mathrm{y}} \mathrm{p} \leq 0.001 \mathrm{v} / \mathrm{s} 15,20$, $25 \mathrm{mg} / \mathrm{L} ; \mathrm{x}_{\mathrm{p}} \leq 0.01 \mathrm{v} / \mathrm{s} 25 \mathrm{mg} / \mathrm{L} ; \mathrm{P}^{\mathrm{p}} \leq 0.05 \mathrm{v} / \mathrm{s} 20 \mathrm{mg} / \mathrm{L}$. Data are mean of three replicates \pm SEM; $0.0=$ Control group.

At $24 \mathrm{~h}$ interval, significant decrease in radicle length was observed in seeds exposed to BPA in a dose-related manner. Furthermore, there was no statistically significant difference reported from $2 \mathrm{mg} / \mathrm{L}$ to $25 \mathrm{mg} / \mathrm{L} \mathrm{BPA}$ treatment at $48 \mathrm{~h}$ as compared to control. In $2 \mathrm{mg} / \mathrm{L}$, $10 \mathrm{mg} / \mathrm{L}$ and $15 \mathrm{mg} / \mathrm{L} \mathrm{BPA}$ treated seeds no statistically significant difference was noticed but in $5 \mathrm{mg} / \mathrm{L}$ and $20 \mathrm{mg} / \mathrm{L}$ significant decrease in radicle length was reported and in $25 \mathrm{mg} / \mathrm{L}$ very significant decrease was observed at $72 \mathrm{~h}$. In BPA treated seeds lowest root length was recorded in $20 \mathrm{mg} / \mathrm{L}$ at $48 \mathrm{~h}(0.85 \pm 0.04)$ and in 25 $\mathrm{mg} / \mathrm{L}$ at $24 \mathrm{~h}(0.35 \pm 0.02)$ and at $72 \mathrm{~h}(1.5 \pm 0.33)$. Maximum root length was recorded in $2 \mathrm{mg} / \mathrm{L}(0.77 \pm 0.04)$ at $24 \mathrm{~h}, 10 \mathrm{mg} / \mathrm{L}(1.5 \pm 0.7)$ at $48 \mathrm{~h}$ and at $2 \mathrm{mg} / \mathrm{L}(3.0 \pm$ $0.03)$ at $72 \mathrm{~h}$ in BPA treated seeds.

\section{Effect of BPA treatment on mitotic index}

The control presented a mitotic index of $17.78 \pm 5.66$ (Fig. 2). However, further increase in BPA concentration caused a decline in the mitotic index in a dose-related manner. As compared to control, at a lesser concentration of BPA ( 2 and $5 \mathrm{mg} / \mathrm{L}$ ), the mitotic index was nonsignificantly lower. When compared with control, in seeds treated with $10 \mathrm{mg} / \mathrm{L} \mathrm{BPA}$, the mitotic index was significantly less $(\mathrm{p}<0.05)$, in $15 \mathrm{mg} / \mathrm{L}$ the mitotic index was found to be very significantly lower $(\mathrm{p}<0.01)$ and in seeds treated with 20 and $25 \mathrm{mg} / \mathrm{L} \mathrm{BPA}$, the mitotic index was highly significantly lower $(\mathrm{p}<0.001)$. In seeds treated with $25 \mathrm{mg} / \mathrm{L} \mathrm{BPA}$, the lowest mitotic index $(5.45$ $\pm 2.05)$ was determined. 


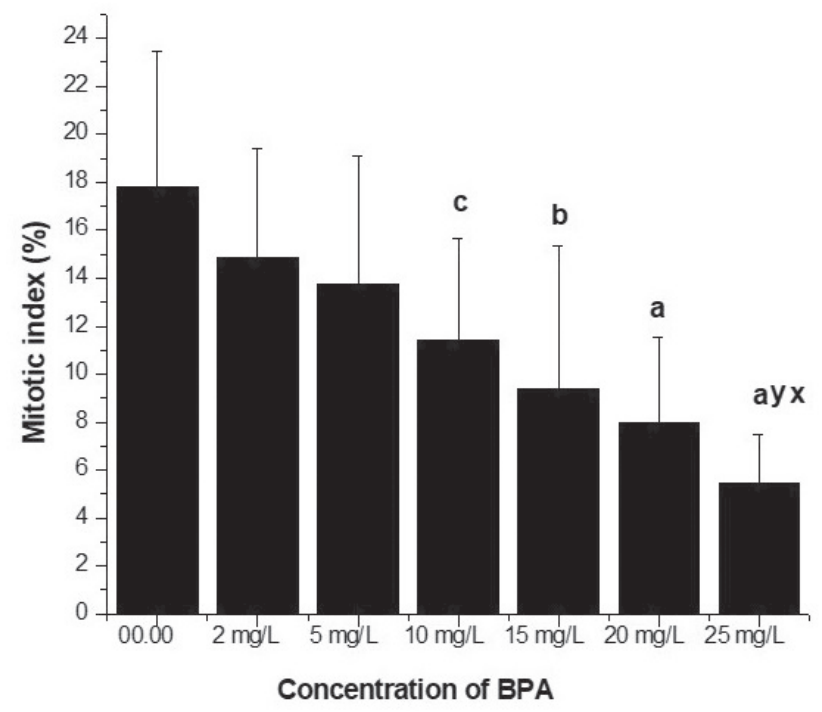

Figure 2. Effect of different concentrations of BPA on the mitotic index in root tip cells of $P$. sativum. ${ }^{\mathrm{a}} \mathrm{p}<0.001$ compared to control; ${ }^{\mathrm{b}} \mathrm{p}<0.01$ compared to control; ${ }^{\mathrm{c}} \mathrm{p}<0.05$ compared to control. ${ }_{\mathrm{p}} \leq 0.001 \mathrm{v} / \mathrm{s} 15,20,25 \mathrm{mg} / \mathrm{L} ;{ }_{\mathrm{p}} \leq 0.01 \mathrm{v} / \mathrm{s} 25 \mathrm{mg} / \mathrm{L}$; Data are mean of three replicates \pm SEM; $0.0=$ Control group.

\section{Effect of BPA treatment on chromosomal anomalies.}

As shown in Table 2 and Fig. 3 treatment with BPA caused numerous mitotic anomalies in $P$. sativum. In control, the occurrence of abnormal metaphase-anaphase plates was $00 \pm 00$. In the present study, in case of root tips of $P$. sativum enhanced occurrence of chromosomal anomalies such as sticky chromosomes, c-mitosis, laggards, bridges and fragments were observed in various doses of BPA treatment (Table 2, Fig. 3). Treatment with BPA resulted in a dose-related increase in the percentage of root tip cells with abnormal metaphase-anaphase plates.

In lower concentration $(2 \mathrm{mg} / \mathrm{L}$ of BPA treatment), minimum chromosomal anomalies such as fragments $(0.42 \pm 0.01)$, c-mitosis $(0.52 \pm 0.01)$, sticky chromosomes $(0.61 \pm 0.01)$, laggards $(0.83 \pm 0.06)$ and bridges $(0.91 \pm$

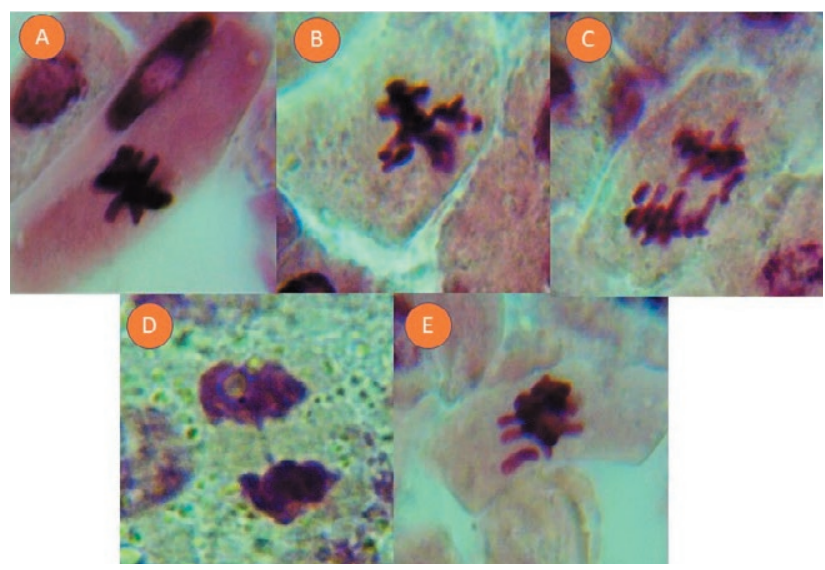

Figure 3. Chromosomal anomalies induced by BPA in $P$. sativum root tip cells. (A) Sticky chromosome, (B) C-mitosis, (C) Laggards, (D) Bridge at anaphase (E) Fragment.

0.02 ) were found which were non-significant ( $>0.05$ ) when compared with control. Highest percentage of bridges $(10.72 \pm 2.2)$, c-mitosis $(8.1 \pm 2.15)$, fragments $(6.78 \pm$ $0.56)$, sticky chromosomes $(6.1 \pm 0.77)$ and laggards (6.01 \pm 2.56 ) were found in $25 \mathrm{mg} / \mathrm{L}$ BPA treated root tip cells.

Sticky chromosomes were highly significant $(\mathrm{p}<0.001)$ in 5 to $25 \mathrm{mg} / \mathrm{L}, \mathrm{c}-$ mitosis was found to be significant $(\mathrm{p}<0.05)$ at $25 \mathrm{mg} / \mathrm{L}$, laggards were found to be significant $(\mathrm{p}<0.05)$ at $20 \mathrm{mg} / \mathrm{L}$, bridges were found to be very significant $(\mathrm{p}<0.01)$ at $10 \mathrm{mg} / \mathrm{L}$ and highly significant $(\mathrm{p}<0.001)$ at 15 to $25 \mathrm{mg} / \mathrm{L}(\mathrm{p}<0.01)$ and fragments were found to be very significant $(\mathrm{p}<0.01)$ at $15 \mathrm{mg} / \mathrm{L}$ and highly significant $(\mathrm{p}<0.001)$ at 20 to $25 \mathrm{mg} / \mathrm{L}$ when compared with control.

\section{DISCUSSION}

The outcome of the present study revealed that BPA inhibits and delays the germination of seeds, mitotic index, radicle length and chromosomal anomalies in

Table 2. Chromosomal anomalies in metaphase-anaphase plates in root tip cells of P. sativum treated with different concentrations of BPA.

\begin{tabular}{|c|c|c|c|c|c|c|c|}
\hline \multirow{2}{*}{ Anomalies in 150 plates } & \multicolumn{7}{|c|}{ Concentrations of BPA } \\
\hline & 00.00 & $2 \mathrm{mg} / \mathrm{L}$ & $5 \mathrm{mg} / \mathrm{L}$ & $10 \mathrm{mg} / \mathrm{L}$ & $15 \mathrm{mg} / \mathrm{L}$ & $20 \mathrm{mg} / \mathrm{L}$ & $25 \mathrm{mg} / \mathrm{L}$ \\
\hline Sticky chromosome (\%) & $00 \pm 00$ & $0.61 \pm 0.01$ & $2.78 \pm 0.09^{\mathrm{a}}$ & $4.99 \pm 0.90^{\mathrm{a}}$ & $4.25 \pm 0.04^{\mathrm{a}}$ & $7.80 \pm 0.44^{\mathrm{a}}$ & $6.10 \pm 0.77^{\mathrm{a}}$ \\
\hline C-mitosis (\%) & $00 \pm 00$ & $0.52 \pm 0.01$ & $3.15 \pm 1.12$ & $2.25 \pm 1.20$ & $5.70 \pm 1.13$ & $6.70 \pm 3.20$ & $8.10 \pm 2.15^{c}$ \\
\hline Laggards (\%) & $00 \pm 00$ & $0.83 \pm 0.06$ & $1.32 \pm 0.91$ & $2.45 \pm 1.01$ & $6.75 \pm 2.05$ & $8.15 \pm 3.25^{\mathrm{c}}$ & $6.01 \pm 2.56$ \\
\hline Bridges (\%) & $00 \pm 00$ & $0.91 \pm 0.02$ & $2.25 \pm 1.00$ & $4.23 \pm 1.20^{\mathrm{b}}$ & $5.78 \pm 0.09^{\mathrm{a}}$ & $7.62 \pm 1.50^{\mathrm{a}}$ & $10.72 \pm 2.2^{\mathrm{a}}$ \\
\hline Fragments (\%) & $00 \pm 00$ & $0.42 \pm 0.01$ & $0.71 \pm 0.45$ & $1.75 \pm 0.76$ & $2.91 \pm 0.66^{\mathrm{b}}$ & $4.62 \pm 0.78^{\mathrm{a}}$ & $6.78 \pm 0.56^{\mathrm{a}}$ \\
\hline
\end{tabular}

${ }^{\mathrm{a}} \mathrm{p}<0.001$ compared to control; ${ }^{\mathrm{b}} \mathrm{p}<0.01$ compared to control; ${ }^{\mathrm{c}} \mathrm{p}<0.05$ compared to control. Data are mean of three replicates $\pm \mathrm{SEM}$; $0.0=$ Control group. 
seeds of $P$. sativum in a dose-related manner. It was shown in our experimental outcome that there is a substantial concentration-effect of BPA on the germination of seeds, mitotic index, radicle length and chromosomal anomalies in seedlings of $P$. sativum (Table 1, 2 and Fig. 1-3).

Seed germination is inhibited by BPA (Zhiyong et al. 2013; Pan et al. 2013; Dokyung et al. 2018)). Similar findings have been found by the present study that BPA delays and inhibits the germination of $P$. sativum seeds. Seed germination is affected by various causes for example light, temperature of incubation, humidity and oxygen level (Isabelle et al. 2000). Eunkyoo et al. (2004) proved that an essential helix-loop-helix transcription feature PIF3-like 5 (PIL5) protein was a significant adverse regulator of phytochrome-mediated germination of seeds. It is known that etiolated seedlings generally have higher quantities of phytochromes A (Hanumappa et al.1999), therefore, the possible functioning of BPA on phytochromes in seeds germination phase is interesting.

In the present test, it was revealed that BPA showed inhibitory effects on root length in $P$. sativum treated with different doses. This may be caused by the noxious influence of BPA in root tips mitotic cell division (Adamakis et al. 2013; 2016; Amer 2017; Dokyung et al. 2018. In P. sativum the root tip mitotic index is directly associated with decrease in root length. The same influence of BPA on mitotic index was recorded (Pan et al. 2013; Jadhav et al. 2012). Primary roots elongation is facilitated by relating hormonal signal paths and a variety of enzymes for example phospholipase $\mathrm{D}$, auxin and phosphatidic acid (Ohashi et al. 2003; Li et al. 2006; Saini et al. 2013). Though, the paths comprised in the molecular process related to the elongation of roots altered by BPA is not known.

The decrease in the quantity of mitotic cells in root tips treated with BPA may be because of its mode of action on the progress of cell cycle. Synthesis of DNA may be inhibited by BPA (Adamakis et al. 2019; Ozge et al. 2019) or in G2 stage of cell cycle, BPA could also obstruct the cells and thus blocking them to enter into mitosis. Moreover, BPA might affect enzymes for DNArepair, by altering the structure of proteins present in the enzymes or in mitotic cells, by decreasing the formation of enzymes at transcription phase that could induce chromosomal anomalies (Ozge et al. 2019; Nasir et al. 2018).

P. sativum seeds treated with BPA showed numerous chromosomal anomalies in root tips mitotic cells for example c-mitosis, bridges, laggards, fragments and sticky chromosomes. The occurrence of chromosomal anomalies increases with increase in BPA concentra- tion. In cell division, spindle fiber arrangement and its movement are a mechanism reliant on ATP (Can et al. 2005; Nasir et al. 2018; Adamakis et al. 2019). Because of decreased synthesis and obtainability of ATP, arrangement of spindle fiber in root tips treated with BPA, cells might get influenced, and it could disturb the chromosomal organization at metaphase plate and chromosomal migration to opposite poles in anaphase. The irregularity in spindles formation and segregation of chromosomes in mitosis, will cause chromosomal anomalies like laggards, bridges and sticky chromosomes.

In BPA treated root tips, C-mitosis is generally linked to spindle defects (Shahin and El-Amoodi, 1991). Since earlier studies have shown that BPA is a strong inhibitor of spindle microtubule organization (George et al. 2008; Adamakis et al. 2013; Xin et al. 2014; Adamakis et al. 2016) which may explain high incidence of C-mitosis in BPA group.

The bridges found in the cells of BPA treated root tips are possibly produced by breaking and merging of chromosome bridges which got enhanced with treatment by BPA. Chromosome bridges may be formed because of stickiness of chromosomes and consequent collapse of freed anaphase separation or because of an uneven translocation or chromosome segment inversion (Gomurgen 2000; Siddiqui 2012; Siddiqui and Al-Rumman 2020 a and b). Moreover, chromosome fragments may get formed because reactive oxygen species can induce double strand breaks in DNA.

\section{CONCLUSION}

Conclusively, the outcome of this investigation revealed that BPA has substantial repressing effects on seed germination and enhances chromosomal anomalies in $P$. sativum root tip cells. As found in the present study and on the basis of the occurrence of numerous types of chromosomal abnormalities, it is rational to presume that BPA might reveal genotoxic effect on plants at elevated concentrations. Moreover, a greater insight into the manner of BPA noxiousness in crops for example $P$. sativum is vital.

\section{ACKNOWLEDGMENTS}

We are grateful to Deanship of Scientific Research at King Khalid University, Abha, Kingdom of Saudi Arabia for providing technical and administrative support. 


\section{FUNDING}

The authors extend their appreciation to the Deanship of Scientific Research at King Khalid University for funding this work through general research program under grant number GRP-33-41.

\section{REFERENCES}

Adamakis ID, Panteris E, Cherianidou A, Eleftheriou EP. 2013. Effects of bisphenol A on the microtubule arrays in root meristematic cells of Pisum sativum L. Mutat Res.750:111-120.

Adamakis ID, Panteris E, Eleftheriou EP. 2016. Bisphenol A disrupts microtubules and induces multipolar spindles in dividing root tip cells of the gymnosperm Abies cephalonica. Chemosphere.149:202-210.

Adamakis ID, Panteris E, Eleftheriou EP. 2019. Tubulin acetylation mediates bisphenol A effects on the microtubule arrays of Allium cepa and Triticum turgidum. Biomolecules. 9(5):185.

Amer Al-Hiyasat. 2017. The effect of bisphenol A on root development and chlorophyll a:b ratio in lens culinaris. International J. of Sciences: Basic and Appl Res. 34(3):115-123.

Can A, Semiz O, Cinar O. 2005. Bisphenol A induces cell cycle delay and alters centrosome and spindle microtubular organization in oocytes during meiosis. Mol Hum Reprod.11:389-396.

Clarke BO, Smith SR. 2011. Review of "emerging" organic contaminants in biosolids and assessment of international research priorities for the agricultural use of biosolids. Environ Int. 37:226-247.

Cooper JE, Kendig EL, Belcher SM. 2011. Assessment of bisphenol A released from reusable plastic, aluminium and stainless-steel water bottles. Chemosphere. 85:943-947.

Dokyung Kim, Jin Il Kwak, Youn-Joo An. 2018. Effects of bisphenol A in soil on growth, photosynthesis activity, and genistein levels in crop plants (Vigna radiata). Chemosphere. 209: 875-882.

Eunkyoo O, Jonghyun K, Eunae P, Jeong K, ChangwonK, Giltsu C. 2004. PIL5, a phytochrome-interacting basic helix-loop-helix protein, is a key negative regulator of seed germination in Arabidopsis thaliana. Plant Cell. 16: 3045-3058.

Ferrara G, Loffredo E, Senesi N. 2006. Phytotoxic, clastogenic and bioaccumulation effects of the environmental endocrine disruptor bisphenol A in various crops grown hydroponically. Planta 223:910-916.

Fu P, Kawamura K. 2010. Ubiquity of bisphenol A in the atmosphere. Environ Pollut.158:3138-3143.
Gatidou G, Thomaidis NS, Stasinakis AS, Lekkas TS. 2007. Simultaneous determination of the endocrine disrupting compounds nonylphenol, nonylphenol ethoxylates, triclosan and bisphenol $\mathrm{A}$ in wastewater and sewage sludge by gas chromatography-mass spectrometry. J. Chromatography A. 1138:32-41.

George O, Bryant BK, Chinnasamy R, Corona C, Arterburn JB, Shuster CB. 2008. Bisphenol A directly targets tubulin to disrupt spindle organization in embryonic and somatic cells. ACS Chem Biol. 3(3):167-79.

Gomurgen AN. 2000. Cytological effect of the herbicide 2,4-D isooctylester $48 \%$ on root mitosis of Allium cepa. Cytologia. 65:383-388.

Hanumappa M, Pratt LH, Cordonnier-Pratt MM, Deitzer GF. 1999. A photoperiod-insensitive barley line contains a light-labile phytochrome B1. Plant Physiol. 119:1033-1039.

Huang H, Tan WJ, Wang CC, Leunga LK. 2012. Bisphenol A induces corticotropin-releasing hormone expression in the placental cells JEG- 3. Reprod Toxicol. 34:317-322.

Isabelle D, Leon-Kloosterziel KM, Koomneel M. 2000. Influence of the testa on seed dormancy, germination, and longevity in Arabidopsis. Plant Physiology. 122:403-413.

Jadhav VV, Jadhav AS, Chandagade CA, Raut PD. 2012. Genotoxicity of bisphenol a on root meristem cells of Allium cepa: A Cytogenetic Approach. Asian J. of Water, Envir and Poll. 9:(1) 39-43.

Le HH, Carlson EM, Chua JP, Belcher SM. 2008. Bisphenol $\mathrm{A}$ is released frompolycarbonate drinking bottles and mimics the neurotoxic action of estrogen in developing cerebellar neurons. Toxic Lett. 176:149156.

Li MY, Qin CB, Ruth W, Wang XM. 2006. Double knockouts of phospholipases Df1 and Df2 in Arabidopsis affect root elongation during phosphate-limited growth but do not affect root hair patterning. Plant Physiol.140:761-770.

Mello MLS, Vidal BC. 1978. A reação de Feulgen. Ciênc Cult. 30:665-676.

Mihaich EM, Friederich U, Caspers N, Hall T, Klecka GM, Dimond SS, Staples CA, Ortego LS, Hentges SG. 2009. Acute and chronic toxicity testing of bisphenol A with aquatic invertebrates and plants. Ecotox Environ Safe. 72:1392-1399.

Mita L, Bianco M, Viggiano E, Zollo F, Bencivenga U, Sica V, Monaco G, Portaccio M, Diano N, Colonna A, Lepore M, Canciglia P, Mita DG. 2011. Bisphenol A content in fish caught in two different sites of the Tyrrhenian Sea (Italy). Chemosphere. 82:405-410. 
Nasir J, Austin RS, Janak L, Pathaka, Shi Y, Chang YC. 2018. Bisphenol A (BPA) the mighty and the mutagenic. Toxicology Reports. 5:76-84.

Noureddin M, Furumoto T, Ishida Y, Fukui H. 2004. Absorption and metabolism of bisphenol A, a possible endocrine disruptor, in the aquatic edible plant, water convolvulus (Ipomoea aquatica), Biosci Biotechn Bioch. 68:1398-1402.

Ohashi Y, Oka A, Rodrigues-Pousada R, Possenti M, Ruberti I, Morelli G, Aoyama T. 2003. Modulation of phospholipid signaling by GLABRA2 in root-hair pattern formation. Science. 300:1427-1430.

Kose O, Rachidi W, Beal D, Erkekoglu P, Fayyad-Kazan H, Kocer Gumusel B. 2020. The effects of different bisphenol derivatives on oxidative stress, DNA damage and DNA repair in RWPE-1 cells: A comparative study. J Appl Toxicol. 40:643-654.

Palani KL, Panneerselvam N. 2007. Cytogenetic studies of food preservative in Allium cepa root meristem cells. Facta universitatis Series: Medi. and Bio. 14(2):60-63.

Pan WJ, Can X, Qiu-P W, Jin-XL, Hong-ML, Wei C, Yong-SL, Lei Z. 2013. Effect of BPA on the germination, root development, seedling growth and leaf differentiation under different light conditions in Arabidopsis thaliana. Chemosphere. 93:2585-2592.

Pothitou P, Voutsa D. 2008. Endocrine disrupting compounds in municipal and industrial wastewater treatment plants in Northern Greece, Chemosphere. 73:716-1723.

Qiu Z, Wang L, Zhou Q. 2013. Effects of bisphenol A on growth, photosynthesis and chlorophyll fluorescence in above-ground organs of soybean seedlings. Chemosphere. 90:1274-280.

Rank J. 2003. The method of Allium anaphase-telophase chromosome aberration assay. Ekologija . 1:38-42.

Saini S, Sharma I, Kaur N, Pati PK. 2013. Auxin: a master regulator in plant root development. Plant Cell Reports. 32:741-757.

Siddiqui S. 2012. Lead induced genotoxicity in Vigna mungo var. HD-94. J. Saudi Society of Agricult. Sci 11;107-112.

Shahin SA, El-Amoodi KHH. 1991. Induction of numerical chromosomal aberrations DNA synthesis using the fungicides nimrod and rubigan-4 Vicia faba L. Mutat. Res. 261:169-176.

Siddiqui S, Al-Rumman S. 2020a . Cytological changes induced by clethodim in Pisum sativum plant. Bangladesh J. Bot. 49(2):367-374.

Siddiqui S, Al-Rumman S. $2020^{\mathrm{b}}$. Clethodim induced pollen sterility and meiotic abnormalities in vegetable crop Pisum sativum L. Caryologia. 73(1):37-44.
Siddiqui S, Meghvansi MK, Hasan Z. 2007. Cytogenetic changes induced by sodium azide (NaN3) on Trigonella foenum-graecum L. seeds. South African J of Bot. 73:632-635.

Speranza A, Crosti P, Malerba M, Stocchi O, Scoccianti V. 2011. The environmental endocrine disruptor, bisphenol A, affects germination, elicits stress response and alters steroid hormone production in kiwifruit pollen. Plant Biol. 13:209-217.

Staples C, Friederich U, Hall T, Kle v cka G, Mihaich E, Ortego L, Caspers N, Hentges S. 2010. Estimating potential risks to terrestrial invertebrates and plants exposed to bisphenol $\mathrm{A}$ in soil amended with activated sludge biosolids. Environ Toxicol Chem. 29: 467-475.

Staples CA, Dorn PB, Kle_GM, O’Block ST, Harris LR. 1998. A review of the environmental fate, effects and exposures of bisphenol A. Chemosphere. 36:21492173.

Stasinakis AS, Gatidou G, Mamais D, Thomaidis NS, Lekkas TS. 2008. Occurrence and fate of endocrine disrupters in Greek sewage treatment plants, Water Res. 42:1796-1804.

Wang LH, Chen LR, Chen KH. 2021. In Vitro and Vivo Identification, Metabolism and Action of Xenoestrogens: An Overview. Int. J. Mol. Sci., 22: 4013.

Wagner M, Oehlmann J. 2009. Endocrine disruptors in bottled mineral water: total estrogenic burden and migration from plastic bottles. Environ Sci Pollut Res. 16:278-286.

Xin F, L Jiang, Liu X, Geng C, Wang W, Zhong L, Yang G, Chen M. 2014. Bisphenol A induces oxidative stressassociated DNA damage in INS-1 cells. Mutat Res Genet Toxicol Environ Mutagen. 769:29-33.

Yamamoto T, Yasuhara A, Shiraishi H, Nakasugi O. 2001. Bisphenol A in hazardous waste landfill leachates. Chemosphere. 42:415-418.

Zhiyong Q, Lihong W, Qing Z. 2013. Effects of bisphenol A on growth, photosynthesis and chlorophyll fluorescence in above-ground organs of soybean seedlings. Chemosphere. 90(3):1274-80. 